\title{
Legal Protection Against Notaries In The Process of Authentic Deed Processing
}

\author{
Afdol, Baby Nita Selly Veronika \\ Faculty of Law, Narotama Universty Surabaya \\ E-mail:Babyveronica459@gmail.com
}

\begin{abstract}
The position of a notary is very necessary in the business world, because it is in accordance with its duties which is to record civil actions and set out in an authentic deed. source of data used in this study is secondary data consisting of primary legal materials in the form of basic norms/rules and related laws and regulations. with the law of protection of notaries in particular The type of research in this legal research is normative legal research, which is a process to find legal rules, legal principles, and legal doctrines in order to answer legal issues faced Engineering and data collection in research This is done by means of library research. Data collection tools used are document studies to obtain secondary data, by reading, studying, researching, analyzing secondary data, secondary and tertiary related to this research.
\end{abstract}

Keywords: Legal protection, notary, authentic deed

\section{INTRODUCTION}

Position of a Notary as a public official is an honorable position given by the State through law to people he trusts. Notary positions cannot be placed in executive, legislative, or judicial institutions. Notaries are expected to have a neutral position, so that if placed in one of the three state bodies, the Notary can no longer be considered neutral. Notaries are expected to be able to provide legal counseling to the public in the field of notary, besides that a Notary is also prohibited from taking sides with his clients, because the Notary's job is to prevent problems. The existence of a notary institution is required by the rule of law with the aim of serving and assisting people who need authentic written evidence. Article 1868 of the Criminal Code states that an authentic deed is a deed made in a form that has been determined by law and made by or before an authorized public official at the place where the deed was made. On the basis of the article above, it becomes the guideline for the promulgation of Law Number 30 of 2004 concerning the Position of a Notary which was promulgated in the State Gazette of the Republic of Indonesia of 2004 Number 117 concerning the Position of a Notary (hereinafter referred to as UUJN) (Reza Berawi: 2009). The definition given by UUJN refers to the duties and authorities carried out by a Notary. A Notary carries out his duties solely not only for the personal interest of the Notary himself, but also for the benefit of the general public (Henricus Subekti: 2006).

The authority of a Notary as stated in Article 15 of the UUJN is to make an authentic deed regarding all actions, agreements, and provisions required by laws and/or desired by the interested 
This work is licensed under a Creative Commons Attribution-ShareAlike 4.0 International License

parties, to be stated in an authentic deed, to guarantee the certainty of the date of making the deed, to keep the deed, provide copies and quotations of the deed, all as long as the making of the deed is not assigned or excluded to officials or other people stipulated by law. Notaries are also authorized to ratify signatures and determine the certainty of the date of making the letter under the hand by registering in a special book (legalization) (Rudianto \& Roesli, 2019). Legalization is the act of ratifying signatures and determining the certainty of the date of an underhand letter made by an individual or by the parties on paper with sufficient stamp duty which is signed before a Notary and registered in a special book provided by a Notary. The authority of the Notary also includes carrying out waarmerking or registering letters under the hand by registering in a special book, making copies of the original letters under the hands in the form of copies containing descriptions as written and described in the letter in question. Notaries are also authorized to ratify the compatibility of photocopies with the original letters (legalized), as well as provide legal counseling in connection with the making of the deed, besides that the Notary can also make a deed related to land and make a deed of auction minutes (Abdul Ghofur: 2009). What is contained in the beginning and end of the deed which is the responsibility of the Notary is an expression that reflects the actual situation at the time of making the deed (Tan Thong Kie: 2000). The position of a notary is very risky and there is very little legal protection, many criminal and civil cases are found involving the notary because of his mistake in making an authentic deed and the parties appearing to be dishonest in the process of making an authentic deed. This legal research discusses the legal protection of notaries in making authentic deeds

\section{RESEARCH METHODS}

In this study, the researchers used three problem approach methods, namely, the statutory approach, the conceptual approach, and the case approach. Thestatute approach iscarried out by reviewing all laws and regulations related to the legal issues being handled. A statutory approach is needed to further examine the regulation of organ transplantation and the authority of a notary in making a deed of use as a prerequisite for a person to become a recipient. In this study, the laws used are;

1. Law No. 30 of 2004 concerning Notary Positions

2. Law No. 2 of 2014 concerning amendments to Law No. 30 of 2004.

Conceptual approach (conceptualapproachdeparts)from the views and doctrines that develop in legal science. Studying the views and doctrines in legal science, researchers will find ideas that give birth to legal notions, legal concepts, and legal principles that are relevant to the issues at hand. The case approach is carried out by conducting an assessment of similar cases and related to the legal issues under study. In this study, primary legal materials were used consisting 
This work is licensed under a Creative Commons Attribution-ShareAlike 4.0 International License

of legislation, official records or minutes in the making of legislation and judges' decisions. Meanwhile, secondary legal materials are all publications on law which are not official documents. Publications on law include textbooks, legal dictionaries, legal journals, and commentaries on court decisions. In this study, the secondary legal materials used include: books in the field of law, papers, articles, and theses. The procedure for collecting and processing legal materials is the first step to collect legal materials, both primary and secondary, related to the research methods used to answer legal issues. Collecting legal materials by researchers by reading books and legislation that have been owned by researchers or by borrowing books from campus libraries and libraries related to the issues to be discussed, as well as conducting interviews with authorized officials. Then the legal materials that have been collected are processed by classifying them based on the legal issues used and then analyzing them.

\section{RESULTS AND DISCUSSION}

\section{History of Notary Institutions Notary}

Institutions in Indonesia date back to the Dutch era, because the Indonesian Notary Position Regulations originated with the Notary Reglement (Stbl. 1660-3) even long ago, namely in 1620. The first notary in the Dutch East Indies was Melchoir Kerchem and his duties are to serve all letters, wills under the hand (codicil), preparation of information, deed of trade contracts, marriage agreements, wills (testament), and other deeds and provisions that are necessary from the municipality and so on. Five years later the number of Notaries has been steadily increasing. Notary appointments are prioritized for candidates who have undergone an apprenticeship period with a Notary (Supriadi: 2006).

The Notary Institution in the Netherlands at that time based on the Emperor's Decree dated November 8 and November 6, 1811, was declared valid in the Netherlands with the first generally accepted regulation in the field of Notary, where previously there were no general provisions governing the Notary Law in the Netherlands. The Netherlands was promulgated on 9 July 1842 Regarding the Notary Position. This law then underwent many changes according to the needs of the community and the development of the times at that time and the changes occurred on December 24, 1970 and finally on July 1, 1999 (Andi Prajitno: 2015). The appointment of a Notary in Indonesia, which at that time was called the Dutch East Indies Archipelago, was aimed at regulating trade competition with a colonial background by controlling the field of trade in a monopoly and at the same time confirming the control of the Dutch government's colonies in the Archipelago. During the Japanese colonial era, there were absolutely no fundamental changes to this profession or institution, both in its functions and regulations. This is because the Japanese colonial period was not too long and very short. The period of the government of the independent 
This work is licensed under a Creative Commons Attribution-ShareAlike 4.0 International License

Republic of Indonesia was divided into 3 (three) periods or periods, based on the enactment of the Law on Notaries, namely:

1. PJN (Regulation of Notary Positions).

2. Law Number 30 of 2004 concerning Notary Positions

3. Law Number 2 of 2014 concerning Amendments to Law Number 30 of 2004 concerning Notary Positions, which is a refinement of Law Number 30 of 2004. The journey of Indonesian notaries has developed in accordance with development of the Indonesian state and nation. This was marked by the success of the Reform Order government in enacting Law Number 30 of 2004 concerning the Position of Notary. This Law Regulation is a substitute for the Notary Position Regulation which is a regulation of the Dutch Colonial Government. Then the last UUJN has been changed so that the latest is Law Number 30 of 2004 concerning Notary Positions.

\section{Understanding the Position of a Notary}

Notary is a profession of trust and different from the profession of a lawyer, where the Notary in carrying out his obligations does not side with any party. Therefore, in his position, the person concerned is trusted to make evidence that has authentic strength. (Wiratni Ahmadi, Sari Wahyuni, Ahmad S. Djoyosugito: 2016) Notary institutions arise because of the community's need in regulating the social life of fellow individuals who need evidence regarding their civil relationship. Therefore, the general power based on the legislation assigns the task to the person concerned by the parties who do it who have authentic power. Article 1 point 1 UUJN explains that a Notary is a public official who is authorized to make an authentic deed and has other authorities as referred to in this law or based on other laws. Article 15 paragraph (1) UUJN, it is explained that: "Notaries have the authority to make authentic deeds regarding all agreements and stipulations required by laws and/or desired by interested parties to be stated in an authentic deed, guarantee the certainty of the date of making the deed, keep the deed, provide grosse, copy and quote of the deed, all of which is as long as the making of the deed is not also assigned by law."

Regarding authentic deeds, Article 1 point 7 UUJN explains that a notarial deed, hereinafter referred to as an authentic deed, is a deed made by or before a notary according to the form and procedure stipulated in this Law.Authentic deed according to Article 1868 of the Civil Code, namely: "An authentic deed is a deed in the form determined by law, made by or before an official public employee who has power for that at the place where the deed was made" 2015 Notary Code of Ethics in article 1 point $4 \mathrm{~m}$ explain that a Notary is any person who assumes and carries out his duties as a public official, as intended and explained in the Law on Notary Positions. So what is meant by public officials in the legal system in the Republic of Indonesia is the only person who serves as a Notary. Thus, what is called a Notary, also includes all employees assigned by the government to carry out all work related to the work of a Notary. 
This work is licensed under a Creative Commons Attribution-ShareAlike 4.0 International License

Notary is a public official who is independent (independent), has the right to regulate, determine the office, both in the form of the location and shape of the building and employees from the amount and salary, not depending on other officials or institutions. If there is the term "Public" in the Notary Position, then the public here means that this official serves the general public in terms of making various or many kinds of authentic deeds related to the field of civil law and this authority has not been delegated to other officials and requested by the public. public who need or have an interest so that their legal actions are stated in the form of an authentic deed and the law requires that it be in the form of an authentic deed whose authority lies with a notary.

Based on the description of the sound of the articles that are still valid, it can be concluded that the only official referred to in the Civil Code Article 1868 is a notary, although Article 1868 only explains what is called an "authentic deed", but does not explain what a "public employee" is. It also does not explain the place where he is entitled or the limits of his authority in such a way, to what extent his rights are and what form according to the law is meant. Article 1868 of the Civil Code relating to UUJN Number 2 of 2014 Article 1 paragraph 1 and paragraph 7, as well as Article 15 paragraph 1 it can be concluded that public employees are public officials and the authentic deed is the Notary's deed.

The reign of the Republic of Indonesia's independence is divided into three (3) the period or periods, based on the enactment of legislation on Notary, namely:

1. PJN (Rule Notary), since its independence until the enactment UUJN (Old Order, New Order, prior to the Reform Order before June 2004)

2. UUJN Number 30 of 2004 (Law Number 30 of 2004 concerning Notary Positions) since the reform order enacted on October 6, 2004

3. UUJN Number 2 of 2014 concerning amendments to Law Number 30 of 2004 concerning Positions Notary which is a refinement.

In carrying out their profession, Notaries are required to comply with the Law of the Republic of Indonesia Number 2 of 2014 concerning Amendments to Law Number 30 of 2004 concerning the Position of a Notary. Notaries also have a Notary Code of Ethics that must be obeyed while still carrying out their profession as a Notary. The code of ethics is also contained in UUJN Article 83 paragraph (1), the article explains that the Notary Organization in this case is the Indonesian Notary Association (INI) establishes and enforces the Notary Code of Ethics.

\section{Duties and Authorities of a Notary Public}

The duties and authorities of a Notary are regulated in Article 1 point 1 of the 2014 UUJN, namely making authentic deeds and other authorities as referred to in the UUJN. Other authorities as referred to in the UUJN refer to Article 15 paragraphs (1), (2) and (3) of the 2014 UUJN. So, to be able to make authentic deeds based on Article 1 of the Regulations on the Position of a Notary, 
This work is licensed under a Creative Commons Attribution-ShareAlike 4.0 International License

they must have the position of a "public official". . Without that position, he does not have the authority to make an authentic deed (R. Soegondo Notodisoerjo: 1982) The word authority in Article 1 of the Regulation of the Position of Notary relates to the provisions in Article 1868 of the Civil Code which states that "an authentic deed is such, which is made in the form determined by law by or before the authorized public official, at the place where it was made. The authenticity of the deed is related to the authority of the notary in making the deed where the authority of the notary is general while the authority of other officials is an exception, the meaning of the word "uitsluitend" (the only one) in article 1 of the PJN is intended to provide confirmation that the notary is the only one who has "certain" authority., meaning that their authority is nothing more than making an authentic deed that is expressly assigned to them by law. One of the conditions that must be met in order for a deed to obtain authenticity is the authority of the notary concerned to make the deed, the notary's authority includes 4 (four) things, namely:

a. The notary is authorized as far as the deed is made. Not all public officials are authorized to make deeds, but a public official can only make certain deeds, namely those assigned or excluded to him based on statutory regulations.

b. A notary is authorized as long as it concerns the person for whom the deed was made. Notaries are not authorized to make deed for the benefit of everyone. In Article 52 paragraph 1 UUJN, it is stipulated that a notary is not allowed to make a deed for himself, his husband/wife, or another person who has a family relationship with a notary either because of marriage or blood relations in a straight line of descent and/or upwards without restrictions. degrees, as well as in a line to the side up to the third degree, as well as being a party to the intermediary of power. The purpose and objective of this provision is to prevent the occurrence of impartial actions and abuse of office.

The notary is authorized as long as it concerns the place where the deed was made. That the deed was made by or before an official who is authorized to make it at the place where the deed was made. So the deed must be made at the place of authority of the official who made it. invalid.

$\mathrm{d}$. The notary is authorized as long as the time of making the deed is concerned. A notary may not make a deed as long as he is on leave or is fired from his position, as well as a notary may not make a deed before he assumes his position (before taking his oath). If one of the above requirements is not met, then the deed made is not authentic and only has the same power as a deed made under the hand, if the deed is signed by the parties. The provisions of Article 1870 of the Civil Code can be concluded that the authentic deed has absolute evidentiary power, especially if the deed makes an agreement that binds both parties who make the agreement. Thus, a Notary is a (Public) Position which has the following characteristics: 
a. As a position,

UUJN is a unification in the field of regulating Notary Positions, meaning that the only legal rule in the form of laws governing Notary Positions in Indonesia, so that all matters relating to Notaries in Indonesia must refer to UUJN. The position of a notary is an institution created by the state. Placing a notary as a position is a field of work or task that is deliberately created by the rule of law for certain purposes and functions (certain authorities) and is sustainable as a permanent work environment.

b. Notaries have certain authority. Every authority given to the position can run well, and does not collide with the authority of other positions. Thus, if an official (notary) commits an act outside the authority that has been found, it can be categorized as an act of violating authority. The authority of a Notary is only stated in Article 15 paragraphs (1), (2) and (3) of the UUJN.

\section{Legal Protection Efforts for Notaries}

The form of legal protection for Notaries in the criminal justice process according to UUJN is the provisions governing the obligation to deny and the rights of Notaries as stated in Article 4 paragraph (2), Article 16 paragraph (1) letter f and Article 54 and Putting fingerprints on the minutes of the deed. Another form of protection can be in the form of Article 16 paragraph (1) letter c, to protect the notary in the form of the approval of the Notary Honorary Council against the summons of a notary. This is regulated in Article 66 paragraph (1) of the Amendment UUJN which states that for the purposes of the judicial process, investigators, public prosecutors or judges are subject to the approval of the Notary Honorary Council. Protection of Notaries as members of the Indonesian Notary Association. The provisions regarding the notary organization are regulated in Article 82 paragraph (2) of the Amendment UUJN which states that the Notary Organization as referred to in paragraph (1) is the Indonesian Notary Association. The core purpose of establishing this association is to provide a guarantee of protection for Notaries with regard to their profession and position as public officials; and Supervision of the practice of the Notary profession. Supervision of Notaries based on Article 67 paragraph (5) Amendments to the UUJN which includes: supervision of Notary behavior and the implementation of Notary positions. Supervision of Notary behavior in the Amendment of the UUJN can be seen in Article 9 paragraph (1) letter c and Article 12 letter c, namely the behavior of a Notary which can be categorized as a disgraceful act and an act that demeans the honor and dignity of the Notary's position, for example gambling, drunkenness, abuse drugs and so on. MPD still has other powers other than those stipulated in Article 66 paragraph (1) UUJN No. 30 of 2004, among others, as regulated in Article 67 UUJN No. 30 of 2004 which states:

(1) Supervision of Notaries is carried out by the Minister. 
(2) In carrying out the supervision as referred to in paragraph (1) above, the minister shall form a Supervisory Council.

(3) The supervisory board as referred to in paragraph (2) consists of 9 people, consisting of 3 government elements.

(4) In the event that an area does not contain elements of government agencies as referred to in paragraph 3 letter a, membership in the supervisory board is filled from other elements appointed by the minister.

(5) The supervision as referred to in paragraph (1) covers the behavior of the notary and the implementation of the notary's position.

(6) Provisions regarding supervision as referred to in paragraph (5) shall apply to substitute Notaries, Special substitute Notaries and temporary notary officials.

The MPD's authority is not only to give written approval in summoning and examining notaries by investigators in their capacity as witnesses or suspects, but more than that, MPD has other powers which are also regulated in UUJN no. 30 of 2004. Therefore, the existence of the MPD as a notary supervisory agency in the district / city area still exists and still has the authority, duties, and responsibilities in carrying out supervision and development of notaries in the regions. Amendments to the Law on Notary Positions No. 30 of 2004 became Law - Law no. 2 of 2014 which was promulgated on January 15, 2014 created new problems in terms of the implementation of Article 66 paragraph (1) as the basis for provisions regarding the protection of Notaries in terms of taking photocopies of the minutes of deed for the purposes of investigations and court examinations by Polri Investigators, Public Prosecutors and Judges., as well as summons by Polri investigators both as witnesses and suspects. This is because Article 66 paragraph (1) UUJN no. 2 of 2014 gives authority to the Notary Honorary Council (MKN), which until now the organization has not been formed. The establishment of the Notary Honorary Council organization requires implementing regulations in the form of a Regulation of the Minister of Law and Human Rights in terms of establishing organizational structures, work procedures and the authority to give written approval to Polri Investigators, Public Prosecutors and Judges.

\section{CONCLUSION}

The position of a notary is very important in the business sector in Indonesia, a notary is tasked with making authentic deeds but there are other authorities such as legalization, making wills, SKMHT, and so on in accordance with the Law on Notary Positions and other laws and regulations and Notaries need extra legal protection to protect themselves and the position they hold. Legal protection can be in the form of fingerprint attachment, right of denial and legal assistance by the supervisory panel. Notaries are obliged to fortify other legal sciences such as 
This work is licensed under a Creative Commons Attribution-ShareAlike 4.0 International License

deepening of knowledge of criminal law and state administration as an additional insight and as a shield for the position of a notary held

\section{REFERENCES}

Ibrahim, A. Kohar (2004), Notary Communicating, Bandung: Alumni.

Subekti, Henricus (2006 ), Notary Duties (Needs) to be Supervised, Renvoi, Number 26, Third Year.

Ghofur, Abdul (2009), Indonesian Notary Institute, Yogyakarta: UII Press.

Kie, Thong, Tan (2000), Notary Studies \& Miscellaneous Notary Practices, Jakarta : Icthiar Baru Van Hoeve.

Sjaifurracman (2011), Aspects of Notary Accountability in Making Deeds, Bandung: Mandar Maju.

Supriadi (2006), Ethics \& Responsibilities of the Legal Profession in Indonesia, Jakarta : Sinar Garfika.

Prajitno (2015), Andi,Practical Knowledge About What and Who is a Notary in Indonesia according to UUJN Number 2 of 2014, Surabaya : Media Archipelago Officers.

Rudianto, E., \& Roesli, M. (2019). Civil Law Review Non-performing Loan Settlement Loans Revolving Funds National Program for Community Empowerment in Urban. YURISDIKSI: Jurnal Wacana Hukum Dan Sains, 14(1), 58-73.

Wiratni, Ahmadi, Wahyuni, Sari, Djoyosugito Ahmad S. (2016), Notary Deed Making Techniques, Bandung : Logoz Publishing.

Notodisoerjo, R. Soegondo (1982), Notary Law in Indonesia, Jakarta: Rajawali.

Adjie, Habib (2005), "The Law on Notary Positions (UUJN) as a Legal Unification of Notary Arrangements". RENVOI, Number 28.

Sutedi, Adrian (2010 ), Notary Testimony is Not an Imperative Legal Obligation in Civil Cases, Jakarta : Pustaka Ilmu 